\title{
Preoperative automatic visual behavioural analysis as a tool for intraocular lens choice in cataract surgery
}

\author{
Análise comportamental visual automática pré-operatória como ferramenta para escolha \\ de lente intraocular em cirurgia de catarata
}

Heloisa Neumann Nogueira ${ }^{1}$, Mônica Alves ${ }^{1}$, Paulo Schor $^{2}$

\begin{abstract}
Purpose: Cataract is the main cause of blindness, affecting 18 million people worldwide, with the highest incidence in the population above 50 years of age. Low visual acuity caused by cataract may have a negative impact on patient quality of life. The current treatment is surgery in order to replace the natural lens with an artificial intraocular lens (IOL), which can be mono- or multifocal. However, due to potential side effects, IOLs must be carefully chosen to ensure higher patient satisfaction. Thus, studies on the visual behavior of these patients may be an important tool to determine the best type of IOL implantation. This study proposed an anamnestic add-on for optimizing the choice of IOL.

Methods: We used a camera that automatically takes pictures, documenting the patient's visual routine in order to obtain additional information about the frequency of distant, intermediate, and near sights.

Results: The results indicated an estimated frequency percentage, suggesting that visual analysis of routine photographic records of a patient with cataract may be useful for understanding behavioural gaze and for choosing visual management strategy after cataract surgery, simultaneously stimulating interest for customized IOL manufacturing according to individual needs.
\end{abstract}

Keywords: Cataract extraction; Cataract/psychology; Lenses, intraocular; Quality of life; Vision, ocular; Visual acuity; Sickness impact profile

\section{RESUMO}

Objetivo: A catarata é a principal causa de cegueira e acomete 18 milhões de pessoas no mundo, com maior incidência na população acima de 50 anos. A baixa acuidade visual causada pela catarata gera um impacto negativo na qualidade de vida de pacientes. O tratamento atualé feito por meio de cirurgia com a substituição do cristalino opacificado por uma lente intraocular (LIO) que pode ser monofocal ou multifocal. No entanto, a escolha da lente intraocular deve ser cuidadosamente realizada para garantir maior satisfação dos pacientes Assim, o estudo do comportamento visual desses pacientes pode ser uma ferramenta importante para definir qual o melhor tipo de lente intraocular a ser implantada. O presente estudo propôs a avaliação de uma ferramenta adicional à anamnese na a escolha da lente intraocular.

Método: Com o uso de uma câmera programada para realizar o registro automático de fotos, foi documentanda a rotina visual do paciente, a fim de se obterem maiores informações sobre a frequência com que o mesmo utiliza a visão para longe, meia distância ou para perto.

Resultados: Os resultados indicaram uma estimativa em porcentagem dessa frequência, sugerindo que a análise dos registros fotográficos da rotina visual de um paciente portadordecataratapodeser de grande ajudanoentendimento do seu comportamento visual e para a escolha da estratégia de reabilitação visual após a cirurgia de catarata e, inclusive, despertar o interesse pela confecção delentes intraoculares personalizadas de acordo com as necessidades de cada paciente.

Descritores: Extração de catarata; Catarata/psicologia; Lentes intraoculares; Qualidade e vida; Visão ocular; Fotografias; Acuidade visual; Perfil de impacto da doença

\section{INTRODUCTION}

Quality of vision is an important part of the quality of life ${ }^{(1)}$; impaired vision therefore has a negative impact on the quality of life by causing difficulties in daily activities and emotional issues ${ }^{(2-4)}$. The progressive increase in life expectancy worldwide is a major public health challenge, placing cataract as one of the important issues. Kara-José et al. ${ }^{(5)}$ estimated the prevalence of cataract in Brazil to be $6.8 \%$ in the agre group of $50-59$ years and as high as $68.3 \%$ in individuals aged above 80 years, indicating a rise prevalence with age.

According to the World Health Organization, 39 million people worldwide are blind, the main cause being cataract ${ }^{(6,7)}$. Daily difficulties due to ocular conditions were reported by $82.7 \%$ of patients in a Brazilian study, in which the most frequently reported difficulties of patients with cataract were walking $(72.5 \%)$, doing housework (64.8\%), and watching television (64.8\%)(8). Thus, cataract indeed greatly impacts the quality of life.
Cataract surgery followed by intraocular lens (IOL) implant can considerably improve vision ${ }^{(2,9)}$. IOL is used after surgery to replace the natural lenses that were removed ${ }^{(10)}$. New materials and different IOL models have been developed and improved to promote better acuity and visual function without the need for glasses ${ }^{(11,12)}$. The monofocal IOL is most commonly implanted in patients undergoing cataract surgery, and enables correction of distance visual acuity; however, glasses are required for near-sighted activities ${ }^{(13)}$. The multifocal IOL corrects distance and near-sighted acuities ${ }^{(14)}$ and reduces the need to wear glasses. There are also strategies such as "monovision," which corrects one eye for far sight and the other eye for near sight, reducing the need for glasses with great success ${ }^{(15,16)}$.

However, despite great improvements in the new generation of lenses, they present side effects, such as intense brightness, formation of halos, and inconsistent intermediate sight ${ }^{(14,15,17)}$, affecting the daily activities and the quality of life of the users ${ }^{(17,18)}$. Therefore, it is 
necessary to carefully select patients to maximize the success of this technology and patient satisfaction ${ }^{(17,19)}$. This selection is made according to the level of patient awareness, and the patient should be made aware of the advantages and limitations of multifocal $I O L^{(20)}$. It is critical to discuss and determine patient expectations because the individual approach and proper patient need assessment are most important when choosing the type of $\mathrm{IOL}^{(13)}$.

Nowadays, we are increasingly multitasking that demand rapid alternation far and near sights such as reading and handling tablets or cell phones while watching television or using a computer and following a GPS while driving. Hence, the ability to quickly focus on objects within variable distances is a common and important activity ${ }^{(17)}$. Analysis of visual behavior can generate relevant information regarding patients with various disorders, particularly in the case of cataract, and be used to inform individual approaches.

Several commercially available devices are used to perform eye tracking to analyze visual behavior under various circumstances. Eye tracking can be used to gain information on how people acquire and process information when reading, browsing the internet, shopping, interpreting image exams, or managing and executing other tasks requiring visual skills to discern the surrounding environment ${ }^{(21)}$. This technology can also be used in the medical field to assess patients with Parkinson's disease ${ }^{(22)}$ or schizophrenia ${ }^{(23)}$, to improve refractive surgery ${ }^{(24,25)}$, and to understand the role of literacy in health ${ }^{(26)}$, among other approaches. Examples of technologies developed for this purpose include EyeLink 1000 and EyeLink II (SR Research), Optical Head Tracking Module and Eye Tracking Glasses (SMI), Tobii X2 30 Eye Tracker, Tobii Glasses 2 Eye Tracker and other models of the Tobii Company, and GP3 Eye Tracker (Gazepoint).

Based on the above, it can be concluded that the visual behavior of patients with cataract is extremely important for deciding the visual strategy to be adopted after phacoemulsification and, consequently, for patient satisfaction and quality of life. This choice is currently based on anamnestic and questionnaire data, obtaining guidelines in relation to visual demands.

New strategies and technological advances to treat cataract-associated visual impairment are in constant evolution and have been rapidly incorporated. Thus, a better understanding of patient behavioural gaze has gained relevance. No tools have been described in the literature that can aid the physician or patient in the choice of these prostheses, and judgment errors may result in discontent and even repeated surgery to remove the lenses. This study proposes a new technology as an add-on to the anamnesis used today, introducing the use of a camera that automatically takes pictures and allows a daily assessment of the visual behavior of patients with cataract.

\section{METHODS}

We used a Narrative Clip camera (http://getnarrative.com/), with the following features: dimensions, $36 \times 36 \times 9 \mathrm{~mm}$; weight, $20 \mathrm{~g}$; capacity, 6000 photographs; image-capture frequency, 30 sec; resolution, 5 megapixels; battery life, 2 days (Figure 1).

In this case series, we selected functionally independent, mentally unimpaired patients with senile cataract. All included patients had already undergone cataract surgery in at least one eye and under similar conditions (phacoemulsification and IOL implant). Also, we collected patient information and a brief report on their daily activities, as a database to be analyzed together with the photographic records.

\section{Patient 1}

Identification: Male, 66 years old, driver.

Report on Daily Activities: After waking up at 6 a.m., the patient drives his car for 20 to 30 min before reaching work. He works from 7 a.m. to 5 p.m., providing internal transport for company staff, driving a van. At night, he has dinner and watches television at an approxi-

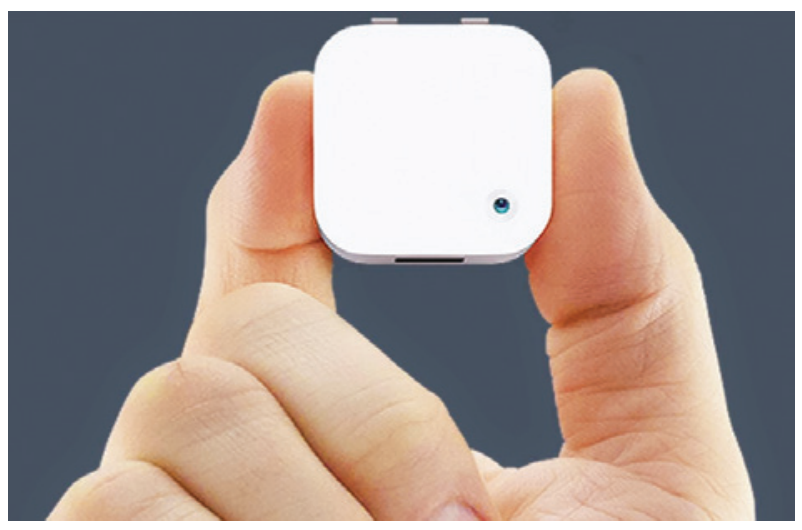

Figure 1. Narrative Clip camera. The image shows the Narrative Clip camera held by an adult hand for size reference. Features: dimensions, $36 \times 36 \times 9 \mathrm{~mm}$; weight, $20 \mathrm{~g}$; capacity, 6000 photographs; image-capture frequency, $30 \mathrm{~s}$; resolution, 5 megapixels; battery life, 2 days.

mate distance of $2 \mathrm{~m}$. He reads the newspaper on a daily basis for approximately $40 \mathrm{~min}$. During his day off and spare time, he watches television, visits family, and does not go out much.

\section{Patient 2}

Identification: Female, 64 years old, teacher.

Report of Daily Activities: After waking up at 6 a.m., the patient has breakfast at home, subsequently spending 10 min of walking to reach her place of work. She works from 7 a.m. to 4 p.m., performing computer tasks and activities that require reading. After work, she walks back home, where she spends most of her time watching television. She usually does not spend much time doing household chores. She reads books on a daily basis for approximately $1 \mathrm{~h}$, and does embroidery two or three times a week.

\section{Patient 3}

Identification: Female, 54 years old, nurse.

Report of Daily Activities: After waking up at 6 a.m. the patient has breakfast at home. She drives or carpools to work; twice a week she goes by bus. She works from 8 a.m. to 5 p.m. in a storeroom of health products purchase and distribution department, which mainly involves using a computer, and also works three night shifts per week in a hospital. She attends Pilates classes three times a week; and on weekends, she visits family, goes to the movies, and watches television. She also attends a post-graduate class once a month.

\section{Patient 4}

Identification: Female, 61 years old, retired lawyer.

Report of Daily Activities: After waking up at 7 a.m., the patient has breakfast at home. She does her household chores, likes to cook, and does hydrogymnastics twice a week. She attends an arts-andcrafts course twice a week and likes to sew. She frequently visits other cities and spends quite a few hours driving every day. She goes to the mall and watches movies and television approximately $1 \mathrm{~h}$ a day.

To compare the references obtained from the reports of daily activities with the photographic records, we classified the activities reported by the patients as follows:

- Driving: Mainly far and intermediate sight and less frequently near sight (checking car dashboard, speedometer, radio, GPS, etc.)

- Watching television: Intermediate sight

- Reading, using the computer and cell phone, doing craftwork, cooking, eating: Near sight

- Talking to other people: Intermediate and near sight

- Walking on the street: Far and intermediate sight 
Patients were instructed to use a shirt with a firm collar reaching the level of the sternal notch, so that the camera could be attached using the clip located on its back side. They were instructed to use the camera throughout the day, immediately on waking up, and to remove it only when its use was considered inappropriate. They were also instructed to point the camera towards the object being observed. The camera was delivered to the patient's home on the previous afternoon, and collected on the day after it was used.

Every 10 records were selected from the photographs recorded by patients using the camera over a period of one day, i.e., at 5-min intervals. The photographs were assessed and classified in terms of distance by our team, as near sight (0-1 m), intermediate sight (1-4 m), or far sight (>4 m). We then evaluated the photographs with each patient, so that they could confirm the distance classification and inform us about the true importance of events recorded. Next, we established the proportion (\%) of time that each patient used near, intermediate, and far sight, according to the number of photographs placed within each of the three classifications versus the total number of photographs selected.

\section{RESULTS}

This study separately assessed the visual behavior of each patient. The results for each patient are enumerated. Because the camera was around the neck and not at the eye level, in certain situations it was not clear what object the patient was looking at. Table 1 shows the proportions (\%) of near, intermediate, and far sight for each patient.

\section{Patient 1}

Patient satisfaction regarding IOL: The patient has a monofocal lens. He is satisfied with his vision and says that he only needs his glasses for activities that require near sight, such as reading.

Table 1. Proportions (\%) of far, intermediate, and near sight

\begin{tabular}{lcccc}
\hline Patient & Patient 1 & Patient 2 & Patient 3 & Patient 4 \\
\hline Far & 4.10 & 2.00 & 19.00 & 18.00 \\
Intermediate & 87.50 & 48.20 & 41.90 & 35.20 \\
Near & 8.40 & 49.80 & 39.10 & 46.80 \\
\hline
\end{tabular}

According to the report on daily activities provided by the patient, we judged that he used mainly far and intermediate sight. The camera was used during his day off. The photographic records matched the activities mentioned by the patient, performed during days off and weekends, where the main activity was watching television. This fact is proven by graph 1 (Figure 2), which shows an intermediate sight proportion of $87.5 \%$, whereas near and far sight proportions were $8.4 \%$ and $4.1 \%$, respectively. In an overall evaluation of his day off, we infer that the patient mainly uses intermediate sight for his daily activities. Figure 2 shows examples of photographs taken by this patient.

\section{Patient 2}

Patient satisfaction regarding IOL: The patient has a monofocal lens in only one eye, and she needs glasses to perform daily activities, because most of her activities require near sight. She has difficulties reading and suffers from eye fatigue.

According to the report of daily activities provided by the patient, we assessed that she used mainly near and intermediate sight. The camera was used during a normal day at work. According to the results shown in graph 2 (Figure 3), the photographic records matched the report of daily activities, with proportions of $49.8 \%$ and $48.2 \%$ for near and intermediate sight, respectively. During photograph evaluation, the patient confirmed all our classifications. Figure 3 shows examples of photographs taken by this patient.

\section{Patient 3}

Patient satisfaction regarding IOL: The patient has a monofocal lens and is satisfied with its performance when using far and intermediate sight. She only needs to use glasses for delicate tasks requiring near sight.

According to the report on daily activities provided by the patient, we judged that she used mainly near and intermediate sight. The camera was used during a vacation day. The photographic records partially matched the classification of the report on daily activities, indicating proportions of $39.1 \%$ and $41.9 \%$ for near and intermediate sight, respectively, as shown in graph 3 (Figure 4). During the photograph evaluation, the patient confirmed all our classifications. Figure 4 shows examples of photographs taken by this patient.
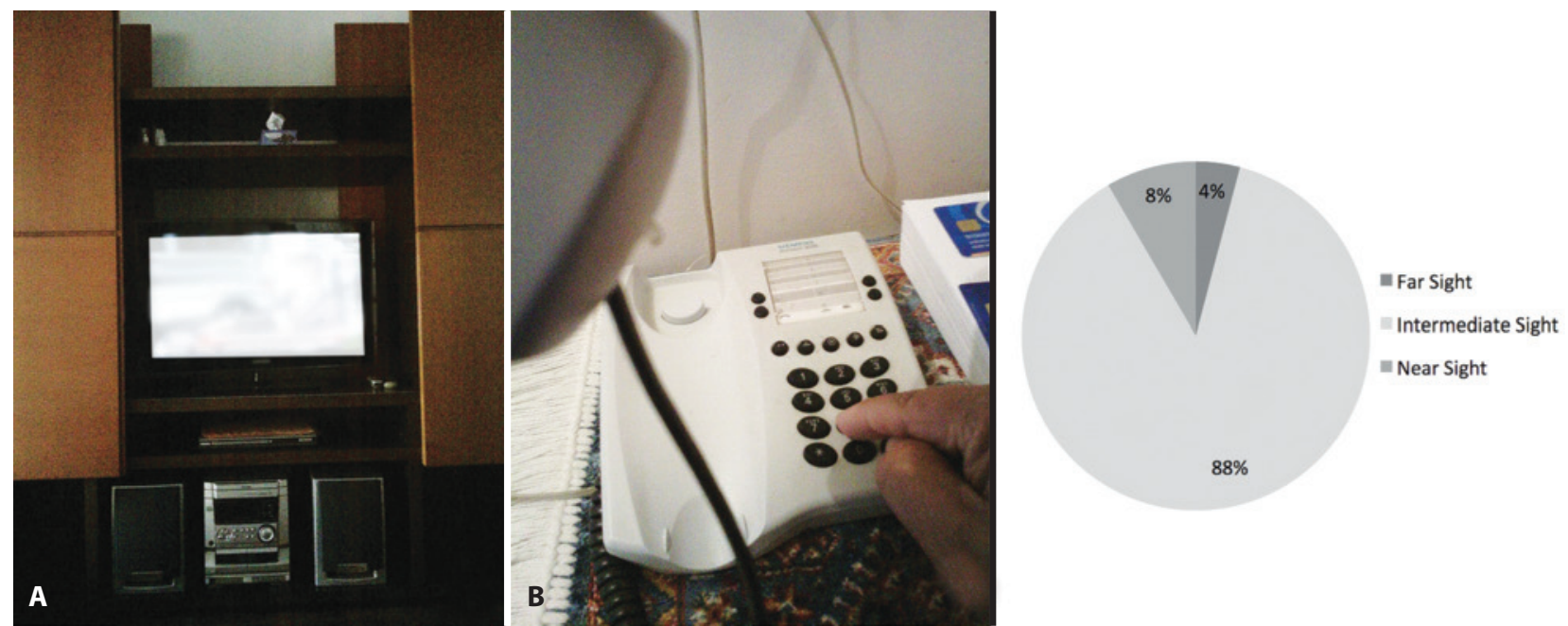

Figure 2. Examples of photographic records obtained by Patient 1 while using the Narrative Clip camera for one day. In image $A$, the patient was watching television (photograph with modified content due to privacy issues); intermediate sight. Image B illustrates the patient using the telephone and reading a book; near sight. Graph 1. Proportion (\%) of time spent by Patient 1 using near, intermediate, and far sight. 

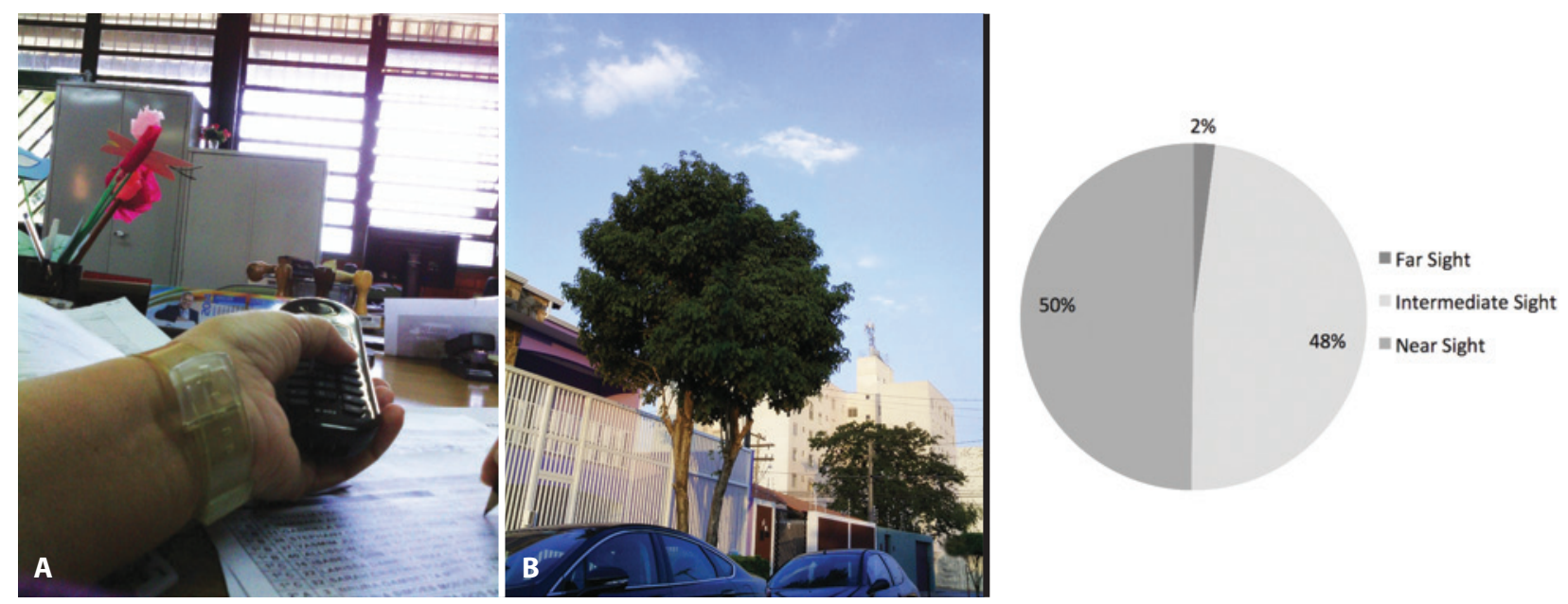

Figure 3. Examples of photographic records obtained by Patient 2 while using the Narrative Clip camera for one day. In image A, the patient was at work; near and intermediate sight. In image B, the patient was walking down the street; intermediate and far sight. Graph 2: Proportion (\%) of time spent by Patient 2 using near, intermediate, and far sight.
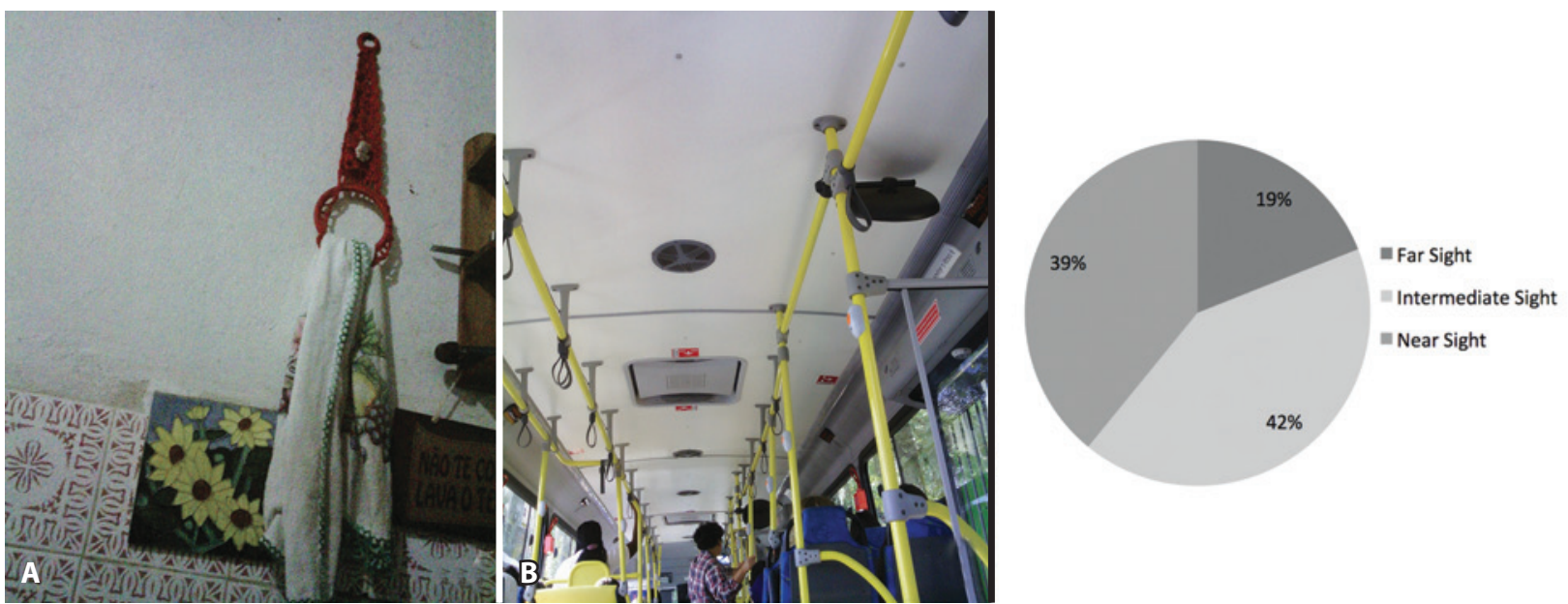

Figure 4. Examples of photographic records obtained by Patient 3 while using the Narrative Clip camera for one day. In image A, the patient was performing household chores; near sight. In image B, the patient was traveling by bus; intermediate and far sight.

Graph 3: Proportion (\%) of time spent by Patient 3 using near, intermediate, and far sight.

\section{Patient 4}

Patient satisfaction regarding IOL: The patient has multifocal lenses in both eyes. She is very satisfied with her near and intermediate sight, but has difficulties with far sight; she says it is too bright and blurry. She also complains of eye pain.

According to the report of daily activities provided by the patient, we considered that she used mainly near and intermediate sight. The camera was used during a normal day of daily activities that, according to the patient, do not vary on weekends because she is retired. The photographic records matched the classification of the report of daily activities, resulting in proportions of $46.8 \%$ and $35.2 \%$ for near and intermediate sight, respectively, as shown in graph 4 (Figure 5). During photograph evaluation, the patient only made few changes to our classifications. Figure 5 shows examples of photographs taken by this patient.

\section{DISCUSSION AND FUTURE PERSPECTIVES}

The choice of IOL after cataract surgery is currently based only on the medical history of patients, so the surgeon can suggest types and brands of available lenses to be implanted. Several studies have been performed to evaluate the best multifocal IOL diopter addition ${ }^{(20)}$. However, knowing the distance at which the patient executes most of his/her daily tasks, i.e., the patient's visual behavior, is critical for choosing an optimal IOL ${ }^{(27-29)}$. Through this unprecedented study, besides achieving a detailed medical history, we were able to add information regarding the type of patient activities performed throughout an entire day; distance estimates of patient sight; and estimates of the proportions of near, intermediate, and far sight. We were therefore able to collect important behavioural gaze data that can lead to developing a better approach toward the patients, including determination of the best type of IOL to be selected for each individual patient and even the more appropriated near vision lens power in multifocal IOLs.

As mentioned earlier, the most commonly used $\mathrm{OOL}$ at present is the monofocal lens, which, when implanted in both eyes, requires the use of near-sighted glasses ${ }^{(13)}$. However, particularly for patients who mostly use near sight in their daily professional or leisure activities, it is necessary to consider alternatives, such as monovision, where one 

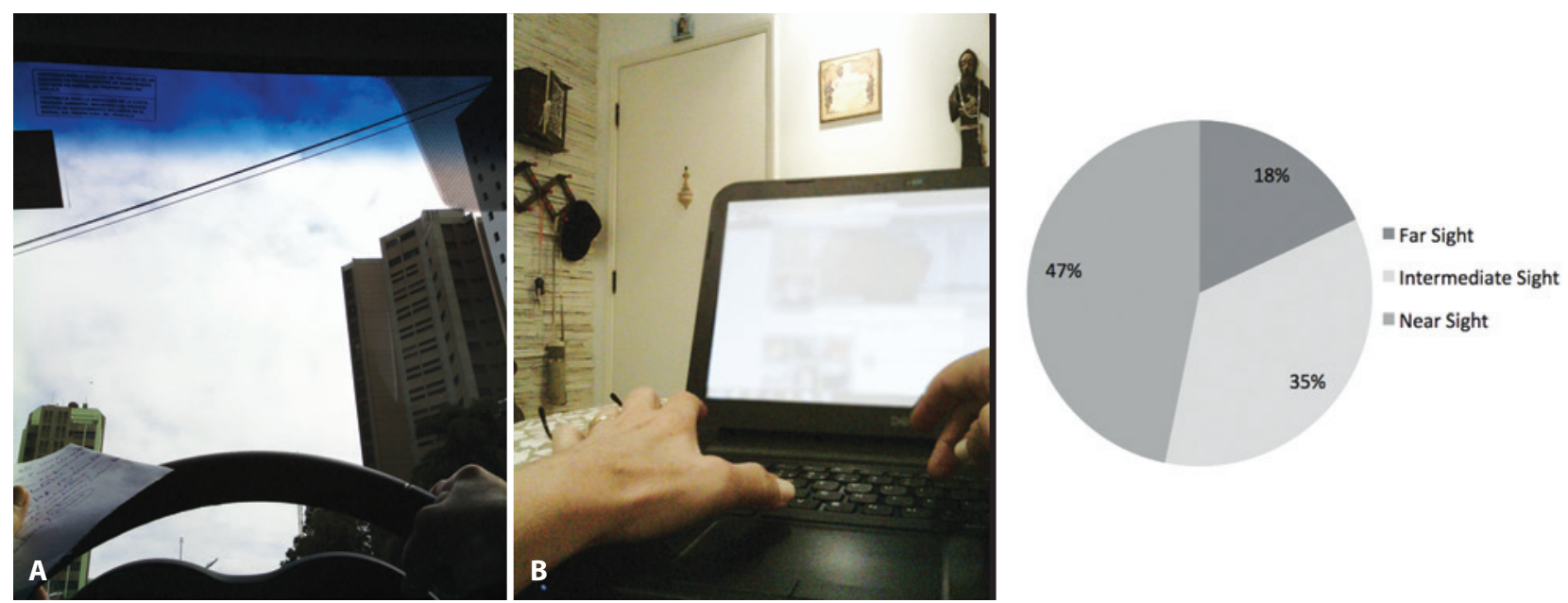

Figure 5. Examples of photographic records obtained by Patient 4 while using the Narrative Clip camera for one day. In image A, the patient was driving; mainly far and intermediate sight but also near sight. In image $B$, the patient was using the computer; near sight. Graph 4: Proportion (\%) of time spent by Patient 4 using near, intermediate, and far sight.

eye is corrected for far sight and the other for the distance most often used by the patient ${ }^{(15,16)}$. Multifocal lenses are also an option, with the second eye focus being adjusted to the patient's needs.

The selected patients had already undergone cataract surgery at least in one eye; hence, it was possible to perform a general assessment of the strategy used for each patient, taking into account the performance of the lenses and the satisfaction of the patients. In the case of Patient 1, who was classified as having mainly far sight, the monofocal lens appeared to have been a good choice. Patient 2 was classified as having mainly near and intermediate sight and was not satisfied with monofocal lenses when carrying out activities requiring near sight. A possible strategy for this case would be monovision with the implant of a lens that corrected the vision of the other eye for near sight, so that the patient would be able to make the most of her vision during daily activities. Another alternative would be to discuss the possibility of implanting a monofocal IOL, which would correct near sight and be compatible with the patient's main needs. Patient 3 was classified as having mainly near and intermediate sight. She had monofocal lenses implanted in both eyes, and she was satisfied with her intermediate and far sight; however, she needed glasses for near sight activities, particularly those related to her work. Therefore, monovision would have been a good strategy for this patient. Patient 4 showed a more even distribution of all three types of sight compared with the other patients, but was classified as having mainly near sight, followed by intermediate sight. She had multifocal lenses implanted in both eyes and reported being very satisfied with her visual performance. The only exception was at night, when she complained about seeing intense brightness and the need for extra light to be able to read. As mentioned earlier, the problems stated by Patient 4 are quite common for patients implanted with this type of $I O L$, and she appeared to be well informed about these issues, which is a determining factor for allocating patients to receiving multifocal lens implants. This leads us to conclude that the strategy used was correct for this patient.

The patients were asked to use the camera for an entire working day. Patients 1 and 3 were on vacation, so their records were consequently compatible with the activity report of leisure days. However, these do not correspond to the tasks they would have performed on a usual working day (professional activities). To obtain a more accurate analysis that would give a full classification of the vision of these patients, it would be necessary to document their activities during a working day. Patient 1 spends most of his time driving, which requires intermediate and far sight more frequently than near sight. As for Patient 2, according to her report of daily activities, the expected result would be a higher proportion of near sight, rather than the result of intermediate sight that was obtained.

All patients showed interest and willingness not only to use the camera to capture the photographs but also to discuss the results, although knowing that they would not directly benefit from this study. We had some difficulty evaluating the photographs with regard to the three types of sight for certain activities - for example, driving involves all three sights - when calculating the proportion of activities involving far, intermediate, and near sights. Despite the fact that the camera was not positioned at eye level, and despite the difficulty in terms of standardizing its height at the level of the sternal notch, the expected final results were not affected. However, it became clear that patients selected for this type of study require good cognitive function to be able to follow the guidance provided by the research team. In addition, a device shaped as a pair of glasses that can determine the distance between the observer and the object could give more accurate photo documentation of the true visual behavior. Furthermore, it would be interesting to have records of data on pupil diameter corresponding to each visual scenario, given the importance of this parameter in the choice of IOL for certain types of bifocal lenses.

With regard to visual behavior, it is important to highlight that this is an issue that involves the individuality of the patient and that has gained importance concerning the improvement of strategies to rehabilitate visual impairment in cataract patients. This is peculiar, since in the medical field diseases are usually analyzed in a general way for a given population. The data obtained were analyzed separately for each patient because only this would allow for an appropriate choice of IOL that would correct their near, intermediate, or far sight, or a combination thereof, according to the needs of each individual patient. We therefore opted to perform an analysis that would estimate the proportion, as a percentage, with which each patient used near, intermediate, or far sight, in order to highlight the importance of the concept of individuality and, in the not so distant future, stimulate interest in the manufacture of personalized IOLs according to the needs of each patient.

This study brings to light a novel method to improve current understanding of behavioural gaze. Our results open up new perspectives on cataract visual impairment rehabilitation but can even be broadly extrapolated as a feasible tool to provide individual evaluation of' visual needs. 


\section{REFERENCES}

1. Stelmack J. Quality of life of low-vision patients and outcomes of low-vision rehabilitation. Optom Vis Sci. 2001;78(5): 335-42.

2. Groessl EJ, Liu L, Sklar M, Tally SR, Kaplan RM, Ganiats, TG. Measuring the impact of cataract surgery on generic and vision-specific quality of life. Qual Life Res. 2013; 22(6):1405-14

3. Castagno VD, Fassa AG, da Silva MC, Carret MLV. Shortage of ocular health care in the public system: a population-based study. Cad Saude Publica. 2009:25(10):2260-72.

4. Medina NH, Muñoz EH. Atenção a saúde ocular da pessoa idosa. Bepa. 2011;8(85):23-8.

5. Kara-José N. Cirurgia de catarata: necessidade social. São Paulo: C \& D; 2008.

6. Petrash JM. Aging and age-related diseases of the ocular lens and vitreous body. Invest Ophthalmol Vis Sci. 2013;54(14):ORSF54-9.

7. Rao GN, Khanna R, Payal A. The global burden of cataract. Curr Opin Ophthalmol. 2011;22(1):4-9.

8. Temporini ER, Kara N Jr, Jose NK, Holzchuh N. Popular beliefs regarding the treatment of senile cataract. Rev Saude Publica. 2002;36(3):343-9

9. Stark WJ, Sommer A, Smith RE. Changing trends in intraocular lens implantation. Arch Ophthalmol. 1989:107(10):1441-4

10. Schuster AK, Tesarz J, Vossmerbaeumer U. The impact on vision of aspheric to spherical monofocal intraocular lenses in cataract surgery: A systematic review with meta-analysis. Ophthalmology. 2013;120(11):2166-75.

11. Akaishi L, Messias CB, Tzelikis PF. Desempenho visual após implante de uma lente intraocular asférica multifocal difrativa. Rev Bras Oftalmol. 2010;69(4): 230-5.

12. lancu R, Corbu C. Premium intraocular lenses use in patients with cataract and concurrent glaucoma: a review. Maedica (Buchar). 2013;8(3):290-6.

13. Synek $S$. The latest generation of intraocular lenses, the problem of the eye refraction after cataract surgery. Coll Antropol. 2013;37 Suppl 1:217-21.

14. Amaral A, Ferreira AS, Cruz P, Silva JP. Avaliação da função visual após implante de lentes intraoculares multifocais-15 a 30 meses de follow-up. Oftalmologia [Internet]. 2011 [citado 2014 Jan 21];35:245-51. Disponível em: http://www.spoftalmologia.pt/ wp-content/uploads/2011/07/revista_spo_n3_2011_pp.245-251.pdf

15. Jain S, Arora I, Azar DT. Success of monovision in presbyopes: review of the literature and potential applications to refractive surgery. Surv Ophthalmol. 1996:40(6):491-9.

16. Xiao $\mathrm{JH}$, Jiang $\mathrm{CH}$, Zhang MN. Pseudophakic monovision is an important surgical approach to being spectacle-free. Indian J Ophthalmol. 2011;59(6):481-5.
17. Cillino G, Casuccio A, Pasti M, Bono V, Mencucci R, Cillino S. Working-age cataract patients: visual results, reading performance, and quality of life with three diffractive multifocal intraocular lenses. Ophthalmology. 2014;121(1):34-44.

18. Alio JL, Plaza-Puche AB, Javaloy J, Ayala MJ, Moreno LJ, Piñero DP. Comparison of a new refractive multifocal intraocular lens with an inferior segmental near add and a diffractive multifocal intraocular lens. Ophthalmology. 2012;119(3):555-63.

19. Lichtinger A, Rootman DS. Intraocular lenses for presbyopia correction: past, present, and future. Curr Opin Ophthalmol. 2012;23(1):40-6.

20. Liu JW, Haw WW. Optimizing outcomes of multifocal intraocular lenses. Curr Opin Ophthalmol. 2014;25(1):44-8.

21. Blignaut P, Wium D. Eye-tracking data quality as affected by ethnicity and experimental design. Behav Res Methods. 2014;46(1):67-80

22. Hochstadt, J. Set-shifting and the on-line processing of relative clauses in Parkinson's disease: results from a novel eye-tracking method. Cortex. 2009:45(8):991-1011.

23. Chen Y. Abnormal visual motion processing in schizophrenia: a review of research progress. Schizophr Bull. 2011;37(4):709-15.

24. Mrochen M, Eldine MS, Kaemmerer M, Seiler T, Hütz W. Improvement in photorefractive corneal laser surgery results using an active eye-tracking system. J Cataract Refract Surg. 2001;27(7):1000-6.

25. Prakash G, Agarwal A, Ashok Kumar D, Jacob S, Agarwal A. Comparison of laser in situ keratomileusis for myopic astigmatism without iris registration, with iris registration, and with iris registration-assisted dynamic rotational eye tracking. J. Cataract Refract Surg. 2011:37(3):574-81.

26. Mackert M, Champlin SE, Pasch KE, Weiss BD. Understanding health literacy measurement through eye tracking. J Health Commun. 2013;18 Suppl 1:185-96.

27. Santhiago MR, Netto MV, Espindola RF, Mazurek MG, Gomes Bde A, Parede TR, et al. Comparison of reading performance after bilateral implantation of multifocal intraocular lenses with +3.00 or +4.00 diopter addition. J Cataract Refract Surg. 2010; 36(11):1874-9.

28. Santhiago MR, Netto MV, Barreto J Jr, Gomes Bde A, Schaefer A, Kara-Junior N. A contralateral eye study comparing apodized diffrative and full difrative lenses: wavefront analysis and distance and near uncorrected visual acuity. Clinics (São Paulo). 2009; 64(10):953-60.

29. Hida WT, Motta AF, Kara-Junior N, Costa H, Tokunaga C, Cordeiro LN, et al. [Comparison between OPD-Scan results and visual outcomes of Tecnis ZM900 and Restor SN60D3 diffractive multifocal intraocular lenses]. Arq Bras Oftalmol. 2008;71(6):788-92. [in Portuguese]. 